\title{
Improvement of Egyptian Clover Yield and Quality by Using Bio and Organic Fertilizers in Newly Cultivated Saline Soil Fatma Sh. Ismail ${ }^{1}$ and Salwa A. A. Hassanen ${ }^{2}$ ${ }^{1}$ Forage Research Department, Field Crops Research Institute, Agricultural Research Center, Giza, Egypt \\ ${ }^{2}$ Central Laboratory of Organic Agriculture, Agricultural Research Center, Giza, Egypt \\ ABSTRACT
}

This work was performed at Sahl El-Hossinia Agric. Res. Station, El-Sharkia, Governorate, throughout winter seasons of the year 2016/2017 and 2017/2018 to investigate the foliar application of compost tea humic acid, and bio-fertilizer on forage production, seeds, chemical analysis of plant and soil. Using bio-fertilizer; humic and compost tea on plant increases significantly the clover yield. Humic acid recorded that increased of values for yield, yield components and quality as compared by other treatments. Results pointed that forage yield was affected by whole treatments under saline soil conditions. In general, berseem clover treated with humic acid increased the plant height, fresh, dry yield, seeds yield, weight of 1000 seeds, crude protein, fiber fraction, Total carbohydrate, digestible crude protein of forage yield as compared with control. Values of $\mathrm{EC}$ and $\mathrm{pH}$ of soil were decline due to various traits using foliar application, while the highest rate of EC in soil run to $\left(5.72 \mathrm{dsm}^{-1}\right)$ at bio-fertilizer. Values of soil properties treated by whole traits were slightly low comparing control $\left(7.72 \mathrm{dsm}^{-1}\right)$. It is clear that the minimum total costs were those of application of Bio-fertilizer, being 4570 L.E and the maximum total costs were those of the plants received Compost-t rate which was 5180 L.E. Average over all treatments of total costs were 4847.5 L.E for the two season. The highest value of net return per one invested L.E was achieved when using humic acid (5.40 L.E) and Compost-t (4.15 L.E) compared with $\mathrm{N}$ fertilization (control 2.63 L.E).

Keywords: Egyptian clover, saline soil, organic and bio-fertilizer and economic evaluation

\section{INTRODUCTION}

Egyptian clover is one of keeping the soil, prevents wind and increases soil organic matter content, particularly in newly reclaimed lands and enhancing soil structure and chemical and physical feature, (Graves et al 1996 and ElNahrawy 2005). Thus, there is a need to develop barseem clover cultivar and appropriate fertilizer types for high forage production and good quality. In Egypt clover (Trifolium alexandrinum L.) is considered long winter forage legume. Its cultivated area almost accumulates more than 1.25 million fed of the total area of around 7.5 million fed. Leguminous crop with high yield and nutritive value, berseem has become one of the basic entries of successive crops in irrigated soils or as a green manure in cash crop rotations Kuneluis Also (1997). Berseem is an annual clover cultivated in irrigated subtropical regions and used as fodder for cattle and milk buffalo. Berseem is significant winter crop in ancient Egypt and was introduced into northern India in nineteenth century. In addition, grown in Europe and the United States (Heuzé et al 2016). Berseem clover is a fast growing, boosting forage quality that is mainly cut and fed as green forage. It is frequently compared to alfalfa, due to its comparable feed value. It is lowest drought-resistant however, it's better on high moisture and alkaline soils. Moreover, berseem sown in nearby Autumn and provide feed before and through colder months Suttie (1999). It is highly productive when temperatures rise after winter (Hannawy and larson 2004 and Suttie 1999). Seeds are massive under favorable conditions. Grazing is possible though less common than cutting. Berseem can be used as green manure (Hannawy and Larson 2004). Humic acid are a fraction of humic substances composed of a long chain molecule, which is high in molecular weight, black colour and soluble in an alkaline solutions. It is consisting from the organic components of soil, humus, peat and coal. It is a byproduct of microorganisms that break down dead organic matter.

They were actually a complex mixture of many different organic acids formed through the biodegradation of organic matter (Sebastiano et al 2005) illustrated that humic acid had a significant impact on growth plant, yield, seed yield, quality and photosynthetic metabolism of wheat crops. Foliar application of humic acid caused a transitional production of plant dry mass with added to control and split soil nitrogen application. (Hussein and Hassan 2011) found that humic acids are vital soil contents; as they can enhance chemical and physical soil features. Organic matter is administrators to arise water holding capacity of the soil, (Vengadaramana and Jashothan 2012). (Singaroval et al 1993) proved that the increase in dry matter production with humic acid might be due to its directly on plant growth axing activity, applied to increase in the dry matter. (Nordi et al 1999) exhibited the biological activity on the humic acid was refer to chemical texture and functional set, which could react with harmonic- binding proteins in the membrane system, evoking a hormone like response. Humic acid content after mineral fertilization was increased to $50 \%$ as compared to control and three times higher with manure application.

Compost-T may be containing that plant growing regulator like substances which contribute to better plant growth and yield Pant et al (2011). Overwhelmingly, compost tea is mixed with boost which is added with a view of rising microbial population through production (Scheuerell and Mahaffee 2004). The use of composts for the maintenance of plant health has been central to the modern organic agriculture movement dating back to the early 1900s Heckman (2006). Over the past century, a result illustrated that composts can suppress plant diseases caused by a variety of pathogens; as well as highest variability of suppression precludes their commercial use for biologically-based disease management in convey by (Hoitink and Fahy 1986; Litterick et al 2004; and Simsek et al 2011). Implementation of compost and bio-fertilizer with influence bed sowing process boosting soil physical characters and wheat yield in saline soils revealed by (Shaban et al 2013). (Tandon, 2000 and Nasef et al 2009) who's that physical characterizes (hydraulic conductivity, bulk density and overall porosity) of salt influenced a soil enhanced when applied are compost, compost tea and biofertilizer. On the other hand, presents that the addition of 
compost (organic) to agricultural in soils has useful impacts on crop planted and yields by enhancing soil physical and biological characterizes (Zheljazkov and Warman 2004). Regions of Mediterranean in the arid and semi-arid, who formed the soil salinization and drought stress mainly which are characterized by high evapotranspiration rates and low rainfall. In these areas, the salts are very low; therefore, salt accumulates in soil surface layers. Since high salts content may adversely affect in soil characters and crop yields, food security could be limited according to (Mariangela and Francesco 2015).

Therefore, salt affected soils must be reclaimed to effect of good maintain satisfactory levels of fertility for sustaining food production. The aim of current investigation was to study the effects of foliar application on Berseem with bio-fertilizer, compost tea and humic acid compared with the control nitrogen fertilizer on some character of quantity and quality for plant, seed yield and physical and chemical characterizes for soil under status of saline soil.

\section{MATERIALS AND METHODS}

The current investigation was carried out during winter seasons of 2016/2017 and 2017/2018 at Sahl ElHossinia Agricultural Research Station in El-Sharkia, Governorate, Egypt. The substantial objective of experiment was to study the effect of treatments application (foliar) of organic acid (compost - tea, humic acid) and bio-fertilizer on physical and chemical soil characterizes, quantity and quality of Egyptian clover (Trifolium alexandrinum L.) under saline soil conditions. Berseem clover (Trifolium alexandrinum L.) c.v. Helaly was supplement from Forage Crops Research Department, Field Crops Research Institute, Agricultural Research Center, Giza, Egypt. Bio-fertilizer, compost tea and humic acid were applied as foliar on plants for three times after 30, 55 and 75 days from sowing. Experimental plots were sown on $10^{\text {th }}$ and $15^{\text {th }}$ October in 2016/ 2017 and 2017/2018. The plot size was $10 \mathrm{~m}^{2}$ (5 m long and $2 \mathrm{~m}$ width). Clover seeds were sown $20 \mathrm{~kg} / \mathrm{fed}$. The experiments were used a randomized complete block design (RCBD) with three replications. Soil samples: Soil samples were taken before planting and ground $0.5 \mathrm{~g}$ powder of each was digested by concentrated digestion mixture of $\mathrm{H}_{2} \mathrm{SO}_{4} / \mathrm{HClO}_{4}$ acids according to (Sommers and Nelson 1972). The surface layer $(0-30 \mathrm{~cm})$ have been obtained from the experimental region, air dried, and ground, sieved by $2 \mathrm{~mm}$ sieve and analyzed for physical and chemical characteristics as given before planting Table (1). After harvest disturbed and undisturbed samples have been collected from surface layers and sub-surface layers at soil depths of 0-30, 30-60 and 60-90 cm. for whole plots through both seasons. The soil samples were air dried and analyzed for physical and chemical properties, according to (Page et al 1982). Total soluble salts were fixed by using electrical conductivity meter at $25^{\circ} \mathrm{C}$ in soil paste extract as $\mathrm{dSm}^{-1}$ Jackson (1976). Total nitrogen was determined by using micro kjeldahel (digestion /distillation unit) according to Jackson (1976). Phosphorus was determined Spectrophotometrcally using ammonium molybedate / stannous chloride method according to Chapman and Pratt (1978). Potassium was set by a flame photometer, according to (Page et al 1982). Fe, Mn, and $\mathrm{Zn}$ were fixed by using atomic absorption (model GBC 932).

Table 1. Some physical and chemical data at the depth of $0-30 \mathrm{~cm}$ of the experimental soil before planting

\begin{tabular}{|c|c|c|c|c|c|c|c|c|}
\hline \multirow{2}{*}{$\begin{array}{l}\text { Course sand (\%) } \\
5.37\end{array}$} & \multirow{2}{*}{$\begin{array}{c}\text { Fine sand ( \%) } \\
23.98\end{array}$} & \multirow{2}{*}{$\begin{array}{c}\text { Silt (\%) } \\
34.49\end{array}$} & \multirow{2}{*}{$\frac{\text { Clay (\%) }}{36.25}$} & \multicolumn{2}{|c|}{ Soil Texture } & \multicolumn{3}{|c|}{$\mathrm{OM}(\%) \quad \mathrm{CaCO}_{3}(\%)$} \\
\hline & & & & Clay Lo & & 0.59 & & 7.94 \\
\hline$\overline{\mathrm{pH}}$ & EC & \multicolumn{4}{|c|}{ Cations $\mathrm{meq}^{-1}$} & \multicolumn{3}{|c|}{ Anions meq $1^{-1}$} \\
\hline$(1: 2.5)$ & $\left(\mathrm{dSm}^{-1}\right)$ & $\mathrm{Ca}^{++}$ & $\mathrm{Mg}^{++}$ & $\mathrm{Na}^{+}$ & $\mathrm{K}^{+}$ & $\mathrm{HCO}_{3}^{-}$ & $\mathrm{Cl}^{-}$ & $\mathrm{SO}_{4}^{-}$ \\
\hline 8.07 & 10.43 & 9.87 & 17.54 & 76.10 & 0.79 & 7.66 & 65.18 & 31.47 \\
\hline \multicolumn{3}{|c|}{ Available Macro - nutrients mg kg-1 } & \multicolumn{6}{|c|}{ Available Micro - nutrients $\mathrm{mg} \mathrm{kg}^{-1}$} \\
\hline $\mathrm{N}$ & $\mathrm{P}$ & $\mathrm{K}$ & $\mathrm{Fe}$ & $\mathrm{Mn}$ & & & $\mathrm{Zn}$ & \\
\hline 37.49 & 3.69 & 189 & 2.61 & 1.53 & & & .56 & \\
\hline
\end{tabular}

Bio-fertilization content: Seed treatment using biofertilizer the symbiotic N-fixing bacteria of Rhizobium leguminosarum bio-vartrifolii (mixture of two isolated Arc 102 and Arc 103) by the Soil Microbiology Unit in soil which provided, Water and Environment Research Institute Agricultural Research Center, Giza, Egypt. Compost analyses: Compost-t was fit by soaking $1 \mathrm{~m}^{3}$ from compost in $1000 \mathrm{~L}$ water, for $48 \mathrm{hrs}$ then filtered and the leached was used as compost-tea and chemical analyses used is shown in Table (2). The compost tea analyses were done according by (Brunner and Wasmer 1978). Composttea is given by Soil Microbiology Unit at Soils Water and Environment Research Institute Agricultural Research Center, Giza, Egypt.

Table 2. Compost-tea analysis

\begin{tabular}{|c|c|c|c|c|c|c|c|c|c|c|}
\hline \multirow{2}{*}{$\begin{array}{l}\mathrm{EC}\left(\mathrm{dSm}^{-1}\right) \\
(1: 10)\end{array}$} & \multirow{2}{*}{$\begin{array}{c}\text { pH } \\
(1: 2.5)\end{array}$} & \multirow{2}{*}{\multicolumn{3}{|c|}{$\begin{array}{c}\text { O.M } \\
(\%)\end{array}$}} & $\mathbf{N}$ & $\mathbf{P}$ & $\mathbf{K}$ & $\mathbf{F e}$ & Mn & $\mathbf{Z n}$ \\
\hline & & & & & \multicolumn{3}{|c|}{ Available (\%) } & \multicolumn{3}{|c|}{ Available (mgkg $\left.{ }^{-1}\right)$} \\
\hline 2.77 & 7.40 & 21.9 & 47.00 & 10.23 & 2.14 & 0.63 & 2.28 & 137 & 88 & 59 \\
\hline
\end{tabular}

Humic acid analyses: Humic acid analyses are an effective agent to determine the carbon, N, P, K, Organic carbon and organic matter as described by Jackson (1967). $\mathrm{Fe}, \mathrm{Mn}$, and $\mathrm{Zn}$ were determined by using Atomic Absorption (model GBC 932), according (Cottenie et al
1961) as Chemical characters' of the humic acid substance in Table (3). This does the Soil Microbiology Unit at Soils, Water and Environment Res. Inst. Agric. Res. Center Giza, Egypt. 
Table 3. Chemical characters of the humic acid

\begin{tabular}{lcccccccc}
\hline \multirow{2}{*}{ pH } & \multirow{2}{*}{ EC $\left(\mathbf{d S m}^{-\mathbf{1}}\right)$} & \multirow{2}{*}{ O.M. $(\boldsymbol{\%})$} & \multicolumn{3}{c}{ Macronutrients (\%) } & \multicolumn{3}{c}{ Micronutrients (mgkg } \\
\cline { 3 - 9 } & & & $\mathbf{N}$ & $\mathbf{P}$ & $\mathbf{K}$ & Fe & Mn & $\mathbf{Z n}$ \\
\hline 7.64 & 2.97 & 72.02 & 1.97 & 0.35 & 3.40 & 397 & 249 & 32.19 \\
\hline
\end{tabular}

Plots were assigned for spraying with the experimental treatments, where:

-(T1) the recommended treatment of inorganic NPK (Control)

- (T2) bio-fertilization (Rhizobium inoculation)

- (T3) compost tea at a rate $400 \mathrm{~L}$ water/fed. (As Foliar)

- (T4) humic acids at a rate $2 \mathrm{~L}$ humic acid/400 L water/fed. (As foliar)

Urea $(46 \% \mathrm{~N})$ was the source of mineral nitrogen fertilizer, which was applied of rate $60 \mathrm{~kg} \mathrm{~N} /$ fed three times 25, 50 and 70 days from sowing at same doses. Super Phosphate was added through soil tillage at 200 $\mathrm{Kg} /$ fed $\left(15.5 \% \mathrm{P}_{2} \mathrm{O}_{5}\right)$. Potassium sulphate $\left(48 \% \mathrm{~K}_{2} \mathrm{O}\right)$ was added at $65 \mathrm{~kg} /$ fed twice 25 and 50 days.

Plant analyses:

In each season three cuts were collected. The first cut was taken 60 days after sowing; the rest cuts were taken every 30 days after the first cut. Samples of each cut of both seasons were collected to determine: length of main stem from soil surface to stem tip; plant height $(\mathrm{cm})$, fresh yield (ton/fed) and dry yield (ton/fed), percentage of DM.

Dry yield $=$ Fresh yield $\times$ Dry matter \%

Biological yield was recorded by harvesting the whole plot and then converted into ton/fed. Seed yield was obtained after harvested from heads after air dried. Weight of thousands seed and weight seeds yield ( $\mathrm{kg} / \mathrm{fed})$. In each cut for the second season, some chemical parameters were determined, i.e., Crude protein (CP \%) was fixed by multiplying the total nitrogen percentage, Total carbohydrate (TC \%) and fiber fraction (ADF, NDF, ADL) percentage according to A.O.A.C. (1990). Digestible crude protein (DCP \%) according to (Mc-Donald et al 1978).

Economic evaluation:

In the present study, the economic evaluation included three parameters that were estimates as follows:

- Average variables as well as total costs of experiment.

- Net farm revenue is the ratios of forage Egyptian clover production particularly to the actual marketing price.

- Net farm return of forage Egyptian clover production. It is the difference between value of forage yield according to the actual price and the total costs.

Statistical analysis: All data were subjected to the statistical analyzed of variance and means were according to procedures outlined by (Gomez and Gomez 1984) using MSTAT-C computer software package (1990). Mean comparisons were made with an F-protected LSD at $\mathrm{P}<0.05$. Bartlett's tests were done to detect homogeneity of the errors variance. The test was insignificant for all treatments, thus combined analysis across two years was by all studied of treatments.

\section{RESULTS AND DISCUSSION}

Effect of different treatment on growth characters and chemical constituents:

I-Growth characters:

1-Plant height (cm): results in Table (4) depict that plant height was affected by bio-fertilizer, compost- $t$ and humic acid, respectively for the two seasons and its combined analysis. The treatment humic acid was the best one where it gave highest mean values $(86.83,85.52$ and $86.18 \mathrm{~cm}$ ) in the two seasons and it's combined, respectively. (Sebastiano et al 2005) showed that humic acid significantly effect on growth, seed yield, quality and photosynthetic metabolic of wheat. These results are harmony with those obtained by (Scheuerell and Mahaffee 2004) illustrated that humic acid (HA) suspensions based potassium humate which have been applied successfully in numerous area of plant production as a plant growth incentive or soil conditioner for improvement natural resistance against plant diseases. Reports had shown that efficiency of humic acid reducing some plant diseases, (Yigit and Dikilitas 2008).

Table 4. Effect of organic (compost-t and humic acid) and bio-fertilization on plant height $(\mathrm{cm})$ of Egyptian clover in 2016/17 and 2017/18 and their combined

\begin{tabular}{lcccc}
\hline \multirow{2}{*}{ Treat. } & \multicolumn{4}{c}{ Season I } \\
\cline { 2 - 5 } Control & Cut I & Cut II & Cut III & Mean \\
Bio-fertilizer & 69.77 & 69.77 & 65.28 & 68.28 \\
Compost-T & 85.53 & 85.53 & 82.54 & 84.54 \\
Humic acid & 78.90 & 82.60 & 79.72 & 80.50 \\
LSD 0.05 & 86.87 & 88.98 & 84.64 & 86.83 \\
\hline \multirow{2}{*}{ Treat. } & 1.32 & 2.10 & 2.31 & 3.62 \\
\hline Control & Cut I & Cut II & Cut III & Mean \\
Bio-fertilizer & 68.49 & 70.35 & 65.81 & 68.22 \\
Compost-T & 80.72 & 84.16 & 79.15 & 81.34 \\
Humic acid & 77.82 & 83.55 & 78.24 & 79.87 \\
LSD 0.05 & 85.50 & 87.32 & 83.73 & 85.52 \\
Treat. & 2.31 & 2.91 & 3.41 & 1.41 \\
\hline Control & \multicolumn{5}{c}{ Comb. } \\
Bio-fertilizer & 83.13 & 84.85 & 80.85 & 82.94 \\
Compost-T & 78.36 & 83.08 & 78.98 & 80.11 \\
Humic acid & 86.19 & 88.15 & 84.19 & 86.18 \\
LSD 0.05 & 4.21 & 3.46 & 3.11 & 2.26 \\
\hline
\end{tabular}

2- Fresh and dry yield: Results in date from Table (5) found that values of fresh and dry yield in barssem clover were affected by different application of organic acid and bio-fertilizers, where the arranged was from 34.37 to 30.16 and from 26.65 to 23.49 and 6.08 to 5.22 and 2.79 to 2.35 ton $\mathrm{fed}^{-1}$ for the first, second seasons and combined, respectively. The application, of organic and bio-fertilizer with respected, it was observed that values of fresh and dry weight affected by different treatment, wherever the addition of bio-fertilizer recorded the lowest values of both fresh and dry yield than the other treatment. Mostly, using humic acid were increased in fresh and dry weight by compared with the control, followed by the compost-t and bio-fertilizer, resp., this results are in harmony with those obtained by (Hussein and Hasan 2011). Referencing the cuts of berseem clover in data appeared that fresh and dry yield rates were excess in $2^{\text {nd }}$ cut as compared with different cuts. These results are confirmed by Abdel 
Gawad (2003) and (Abotaleb et al 2008) noticed that highest fresh yield of barseem was obtained from the second and/or the third cut at 8-12 weeks after planting, where the environmental conditions prevailed during that period were optimum for berseem growth and production by (Khaled et al 2011) proved that better growth was due to boost soil nutrient availability and uptake by plants organic manure substantially enhance shoot and root dry weights influenced by the application of various organic materials composted. Mohamed and Ashok (2014) illustrated that total dry matter of sorghum was highly significant. Highest DM yield was produced in treatment where Compost of Farm Yard Manure (FYM), humic acid and press mud were applied in combination followed by the traits where some soil properties (SSP) and compost of FYM were applied

3-Seed Yield: Data in Table (6) shown that weight of seeds yield $\left(\mathrm{kg} \mathrm{fed}^{-1}\right)$ and weight of 1000 seeds $(\mathrm{g})$ was affected by bio-fertilizer, compost-t and humic acid, respectively for the combined over the two seasons. The result mean values for weight of seeds were $(273,256,238$ and $199 \mathrm{~kg} \mathrm{fed}^{-1}$ ), respectively for humic acid, compost-t, bio-fertilizer and control, while weight of 1000 seeds (g) were recorded the highest mean value $2.38 \mathrm{~g}$ in humic acid treatment. (Ferrara and Brunetti 2010) exhibited that humic acid is most active component of soil organic matter and shown to have a hormone like activity which boosts growth. Application of humic acid was effect significantly on plant growth parameters sown in saline condition, indicated that by (Turkmen et al 2005).

Positive results may be to humic acid as applied it has a promoting effect on plant parameters under saline soil. (Boris et al 2010) found that humic acid attributes were influenced on growth and physiological characters and their effects may depend on hormones and development.

Table 5. Effect of organic (Compost-T and humic acid) and bio-fertilization of fresh and dry yields of berseem clover in 2016/17 and 2017/18 and their comb

\begin{tabular}{|c|c|c|c|c|c|c|c|c|c|c|c|c|}
\hline \multirow{3}{*}{ Treat. } & \multicolumn{12}{|c|}{ Fresh yield (ton /fed) } \\
\hline & \multicolumn{4}{|c|}{ Season I } & \multicolumn{4}{|c|}{ Season II } & \multicolumn{4}{|c|}{ Comb. } \\
\hline & Cut I & Cut II & Cut III & Total & Cut I & Cut II & Cut III & Total & Cut I & Cut II & Cut III & Total \\
\hline Control & 8.92 & 9.55 & 8.19 & 26.65 & 7.80 & 8.25 & 7.44 & 23.49 & 8.36 & 8.90 & 8.16 & 25.42 \\
\hline Bio-fertilizer & 9.72 & 10.24 & 9.22 & 29.17 & 8.92 & 9.13 & 8.67 & 26.72 & 9.32 & 9.69 & 8.95 & 28.33 \\
\hline Compost-T & 10.64 & 11.34 & 9.71 & 31.69 & 9.28 & 9.91 & 9.16 & 28.35 & 9.96 & 10.63 & 9.44 & 30.03 \\
\hline Humic acid & 11.41 & 12.16 & 10.80 & 34.37 & 9.98 & 10.54 & 9.64 & 30.16 & 10.70 & 11.35 & 10.22 & 32.27 \\
\hline \multirow[t]{2}{*}{ LSD 0.05} & 0.65 & 0.63 & 0.89 & 2.04 & 0.76 & 0.61 & 0.91 & 1.54 & 0.63 & 1.10 & 0.85 & 2.50 \\
\hline & \multicolumn{12}{|c|}{ Dry yield (ton/ fed) } \\
\hline \multirow[t]{2}{*}{ Treat. } & \multicolumn{4}{|c|}{ Season I } & \multicolumn{4}{|c|}{ Season II } & \multicolumn{4}{|c|}{ Comb. } \\
\hline & Cut I & Cut II & Cut III & Total & Cut I & Cut II & Cut III & Total & Cut I & Cut II & Cut III & Total \\
\hline Control & 0.88 & 1.01 & 0.90 & 2.79 & 0.74 & 0.92 & 0.69 & 2.35 & 0.81 & 0.97 & 0.80 & 2.58 \\
\hline Bio-fertilizer & 1.12 & 1.86 & 1.45 & 4.43 & 1.49 & 1.85 & 1.06 & 4.40 & 1.31 & 1.86 & 1.26 & 4.43 \\
\hline Compost-T & 1.15 & 1.89 & 1.72 & 4.76 & 1.64 & 1.91 & 1.17 & 4.72 & 1.40 & 1.90 & 1.45 & 4.75 \\
\hline Humic acid & 2.01 & 2.17 & 1.90 & 6.08 & 1.90 & 2.14 & 1.17 & 5.22 & 1.96 & 2.16 & 1.54 & 5.66 \\
\hline LSD 0.05 & 0.19 & 0.21 & 0.33 & 0.48 & 0.22 & 0.14 & 0.31 & 0.29 & 0.20 & 0.11 & 0.10 & 0.16 \\
\hline
\end{tabular}

Table 6. Impact of compost-T, humic acid and biofertilization on weight of 1000 seed and seed yield of Egyptian clover in 2016/17 and $2017 / 18$ as well as combined

\begin{tabular}{lccc}
\hline \multirow{2}{*}{ Treat. } & \multicolumn{3}{c}{ Weight of 1000 seeds (g) } \\
\cline { 2 - 4 } & First season & Second season & Comb. \\
\hline Control & 2.25 & 2.29 & 2.27 \\
Bio-fertilizer & 2.31 & 2.34 & 2.33 \\
Compost-T & 2.33 & 2.36 & 2.35 \\
Humic acid & 2.35 & 2.41 & 2.38 \\
LSD 0.05 & NS & NS & NS \\
Treat. & \multicolumn{4}{c}{ Seeds yield (kg /fed) } \\
\cline { 2 - 4 } Control & First season & Second season & Comb. \\
Bio-fertilizer & 198 & 200 & 199 \\
Compost-T & 245 & 230 & 238 \\
Humic acid & 253 & 259 & 256 \\
LSD 0.05 & 269 & 277 & 273 \\
\hline
\end{tabular}

\section{II - Chemical constituents:}

The effect of organic acid and bio-fertilizer on the crude protein content is presented in Table (7), Egyptian clover treated by control, compost, bio-fertilizer and humic acid accumulated the values $\mathrm{CP}$ ranged from 14.68 to $19.05 \%$ and the treatment which used humic acid gave the highest value $19.05 \%$ while the treatment which used compost-t gave the lowest ratio $14.68 \%$. Berseem clover was superior in the $\mathrm{CP}$ content with humic acid fertilizer, while the same treatment recorded the lowest value with total carbohydrate and fiber fractions (Waldo and Jorgensen 1981). The researcher suggests conducting animal feeding trials to investigate the response of ruminants to the forage with organic acid especially humic acid. Total carbohydrate content was recorded the lowest value with humic acid fertilizer of the berseem clover, equivalent to $60.46 \%$ when nitrogen fertilizer was applied. Forage legumes are recognized to have higher crude protein and cell wall fractions, however, lower total carbohydrates.

The lowest values of total carbohydrate content amounting $60.46 \%$ when humic acid was applied. Forage legumes are known to have higher protein and cell wall fractions, however, lower contents of carbohydrate. Nor El-Din (1978) showed that crude protein were higher in humic acid followed bio-fertilizer than other treatments in the second seasons. Values of digestible crude protein recorded the highest value for digestible in treatment humic acid followed; biofertilizer 13.69, $12.58 \%$ respectively. The data presented in Table (7) indicated that low significant NDF and ADF contents were produced from humic acid. The ADL content gave the lowest value with humic acid treatment followed; compost-t and biofertilizer. Forage legumes are generally higher in lignin, results by Laidlaw and Teuber (2001). 
Table 7. Effect of organic (compost-t and humic acid) and bio-fertilization of chemical constituents' percentage and fiber fraction of Egyptian clover (combined analysis)

\begin{tabular}{lcccccc}
\hline Treat. & CP \% & TC \% & DCP \% & ADF (g/kg) & NDF(g/kg) & ADL (g/kg) \\
\hline Control & 15.25 & 78.08 & 10.23 & 315.47 & 465.49 & 40.90 \\
Bio-fertilizer & 17.83 & 76.90 & 12.58 & 296.38 & 426.48 & 39.20 \\
Compost-T & 14.68 & 71.18 & 9.71 & 276.63 & 423.35 & 38.29 \\
Humic acid & 19.05 & 60.46 & 13.69 & 272.04 & 399.16 & 37.10 \\
\hline LSD 0.05 & 0.53 & 1.10 & 1.00 & 4.23 & 2.99 & 0.89 \\
\hline
\end{tabular}

Effect of different treatments on soil physical and chemical characters' of experimental site after clover harvest:

1- Electric conductively (E.C. $\left.\mathrm{dSm}^{-1}\right)$ :

Table (8) presents soil EC were decline due to application of whole treatments compared with control $\mathrm{N}$ fertilizer using foliar application in the experimental plot units, while application of compost on salt affected soil helps in diminishing salinity and improving soil characteristics, mainly by the increase of salts leaching. The highest mean value of EC in soil gave $\left(5.72 \mathrm{dSm}^{-1}\right)$ in case comb. of bio-fertilizer than other treatments of fertilizer. These results are agreement and reported by (Abdurrahman et al 2004) and (Hussein and Hassan 2011) observed the mean values of EC in soil can be arranged according on the other hand to the following order; humic acid, bio-fertilizer, compost-tea and control of foliar applied.

Table 8. EC ( $\left.\mathrm{dSm}^{-1}\right)$ and $\mathrm{pH}$ available in soil after clover harvest (average of the two seasons and comb.)

\begin{tabular}{lcccccc}
\hline \multirow{2}{*}{ Treat. } & \multicolumn{3}{c}{$\mathbf{E C}\left(\mathbf{d S m}^{-\mathbf{1}}\right)$} & \multicolumn{3}{c}{$\mathbf{p H}$} \\
\cline { 2 - 7 } & Season I & Season II & Comb. & Season I & Season II & Comb. \\
\hline Control & 8.10 & 7.34 & 7.72 & 8.09 & 8.05 & 8.07 \\
Bio-fertilizer & 5.87 & 5.57 & 5.72 & 7.95 & 7.93 & 7.94 \\
Compost-T & 5.21 & 4.33 & 4.77 & 7.98 & 7.95 & 7.97 \\
Humic acid & 5.98 & 5.29 & 5.64 & 7.94 & 7.95 & 7.95 \\
\hline
\end{tabular}

\section{2- pH available in Soil:}

The one of most important parameters is soil $\mathrm{pH}$, which overall changes in soil chemical characters. Data Table (8) shown that soil $\mathrm{pH}$ was declined slightly due to application of humic acid, bio-fertilizer, and compost-tea as compared with other applied of fertilization. Compost fertilizer extracts were recorded decreased of $\mathrm{pH}$, salinity (EC, for lower dilutions) and $\mathrm{K}$ concentration, while raised slightly $\mathrm{N}, \mathrm{P}, \mathrm{Ca}$, and $\mathrm{Mg}$ concentrations when used as a source of nutrients for plant growth. Rebeka (2006) obtained those results found that the same. Soil $\mathrm{pH}$ slight was declined values may be reflect the activity of microorganisms in decomposing $\mathrm{OM}$ and releasing organic acids. Addition of compost and different mineral nitrogen fertilizer rates, slightly were decreased the $\mathrm{pH}$ values in tested soil, reported that result by Gehan (2006).

\section{3 - Macro-Micronutrients content available in soil after} clover harvest:

Available (NPK) and (Fe, Mn and $\mathrm{Zn}) \mathrm{mg} / \mathrm{kg}$ in soil. Data in Table $(9 a-9 b)$ revealed that the values of macro and micronutrients content of available in soil after clover harvest (N, P, K, Fe, Mn and Zn) mg/kg in soil amounts were increased significantly by different the others treatment, results indicated that available $\mathrm{P}$ and $\mathrm{K}$ affected by compost- $T$ addition. Data found that the highest values of macro-micronutrient follow this order; compost tea, bio-fertilizer, humic acid with foliar applied compared to control treatment, respectively. Observed that using of composted manure $(50 \mathrm{~kg} \mathrm{~N} / \mathrm{fed})$. Inoculation reveled higher values of $\mathrm{N}, \mathrm{P}$ and $\mathrm{K}$ uptake than the full does (100kg N/fed.) of no organic $\mathrm{N}$-fertilizer or organic manure, obtained that results by El-Sebaey (2006). On other hand of similar these result about (Samah and
Bashandy 2007), revealed that N, P, K uptake of crops sown in compost was higher than of crops grown on the untreated soils. Regarded to application treatments, the results demonstrated that potassium by plants increased by various addition treatments of organic alone or combined with other fertilizer, the compost-t addition treatment was gave highly significantly values of macronutrients compared with other treatments.These results according with that gained by Holah (1990), Mekail (2006) and (Mostafa et al 2001) evident that the applied using of organic manures concrete was evolution available of Fe, $\mathrm{Mn}$ and $\mathrm{Zn}$ contents. The lowest values of $\mathrm{Fe}, \mathrm{Mn}$ and $\mathrm{Zn}$ were observed in case of control $\mathrm{N}$ fertilizer foliar application, the results showed that Iron by plants increased by different addition treatments of organic acid or join with other fertilizers, the compost- $t$ addition treatment were highly significant of micronutrients compared with other treatments. As for as, data that the potassium in plant was significantly, as affected by using organic only or combined with other fertilizers, which are ranges of the potassium from 214 to $203(\mathrm{mg} / \mathrm{kg})$. As for Iron in plant, data revealed that Iron was highly significant as affected by using organic only or combined with other treatments, where are ranges of the Iron from 2.86 to 2.73 (mg / kg plant). (El- Sedfy et al 2005) and (Modaihsh et al 2005) pointed that application of compost at levels increment available $\mathrm{Zn}$ and organic matter when applied at 5 tons compost- $t$ in soil overtake the organic matter content from $0.48 \%$ to $0.58 \%$. (Hammad et al 2006 ) found that combination of rice straw compost in addition nitrogen fertilizer raising availability of $\mathrm{Fe}, \mathrm{Mn}$ and $\mathrm{Zn}$ in tested soil. (Abdel-Aal et al 2003) reported that the same conclusion when setting the same treatment addition. 
Table 9a. Effect of foliar application with some aliment available NPK in soil $\mathrm{mg} / \mathrm{kg}$ concentration in soil after harvest clover plants during 2016/17 and 2017/18 seasons and their combined

\begin{tabular}{|c|c|c|c|c|c|c|c|c|c|}
\hline \multirow{2}{*}{ Treat. } & \multicolumn{3}{|c|}{ N (mg /kg) } & \multicolumn{3}{|c|}{ P (mg / kg) } & \multicolumn{3}{|c|}{ K (mg /kg) } \\
\hline & Season I & Season II & Comb. & Season I & Season II & Comb. & Season I & Season II & Comb. \\
\hline Control & 40.88 & 41.58 & 41.23 & 3.69 & 4.06 & 3.98 & 195 & 198 & 196.0 \\
\hline Bio-fertilizer & 42.79 & 43.12 & 42.96 & 4.06 & 4.18 & 4.12 & 203 & 196 & 199.5 \\
\hline Compost-t & 43.62 & 43.97 & 43.80 & 4.13 & 4.28 & 4.21 & 214 & 214 & 214.0 \\
\hline Humic acid & 42.74 & 43.68 & 43.21 & 4.02 & 4.10 & 4.06 & 213 & 213 & 213.0 \\
\hline LSD 0.05 & 0.78 & 0.88 & 0.55 & 0.06 & 0.09 & 0.08 & 7.16 & 16.35 & 12.65 \\
\hline
\end{tabular}

Table 9b. Effect of foliar application with some aliment available $\mathrm{Fe}, \mathrm{Mn}$ and $\mathrm{Zn}$ in soil concentration after sowing in both seasons and their combined

\begin{tabular}{lccccccccc}
\hline \multirow{2}{*}{ Treat. } & \multicolumn{3}{c}{ Fe mg /kg } & \multicolumn{3}{c}{ Mn mg/kg } & \multicolumn{2}{c}{ Zn mg /kg } \\
\cline { 2 - 9 } & Season I & Season II & Comb. & Season I & Season II & Comb. & Season I & Season II & Comb. \\
\hline Control & 2.67 & 2.70 & 2.65 & 1.26 & 1.29 & 1.27 & 0.61 & 0.63 & 0.62 \\
Bio-fertilizer & 2.75 & 2.79 & 2.77 & 1.69 & 1.73 & 1.71 & 0.66 & 0.68 & 0.67 \\
Compost-T & 2.85 & 2.87 & 2.86 & 1.74 & 1.77 & 1.76 & 0.74 & 0.76 & 0.71 \\
Humic acid & 2.76 & 2.59 & 2.73 & 1.71 & 1.74 & 1.73 & 0.69 & 0.71 & 0.70 \\
\hline LSD 0.05 & 0.06 & 0.07 & 0.08 & 0.02 & 0.09 & 0.12 & 0.04 & 0.04 & 0.03 \\
\hline
\end{tabular}

Economic evaluation:

Costs: Total costs including values of production tools and requirements such as seeds, fertilizers, irrigation, man power, machinery and other general or miscellaneous costs without land rent average summer 2016/2017 and 2017/2018 seasons are shown in Table (10). The cost of 50 kilogram urea was $100 \mathrm{~L}$.E. added at rate $60 \mathrm{~kg} \mathrm{~N} /$ fed for three times 25, 50 and 70 days from sowing, the cost of 50 kilogram super phosphate $15.5 \%$ was 65 L.E. (added during soil tillage at $200 \mathrm{~kg} \mathrm{P}_{2} \mathrm{O}_{5} / \mathrm{fed}$ ) and the price of 50 kilogram potassium sulphate was $250 \mathrm{~L} . \mathrm{E}$ added at $65 \mathrm{~kg}$ $\mathrm{k}_{2} 0$ /fed on two times 25 and 50 days from planting. Biological yield was recorded by harvesting the whole plot and then converted into ton/fed. Seed yield was obtained after separated from heads plant after air dried material. Thousand seed weight ( $\mathrm{g}$ ) the price of one kilogram seeds was $30 \mathrm{~L}$. E. the total cost of soil tillage involved the price for plowing by chisel plow was 300 L.E. Data depicted in Table (10) found that total prices of Egyptian clover production per feddan as influenced by the applied treatments (average of 2016/17 and 2017/18).

Table 10. Estimated net return L.E.fed. ${ }^{-1}$ of forage Egyptian clover treated with mineral, compost, bio- fertilizer and humic acid across of the two seasons 2016/17 and 2017/18

\begin{tabular}{|c|c|c|c|c|}
\hline $\begin{array}{l}\text { Treatments } \\
\text { Cost of production inputs }\end{array}$ & Control & Compost- tea & Bio - fertilizer & Humic acid \\
\hline \multicolumn{5}{|l|}{ land preparation } \\
\hline Tillage & 300.00 & 300.00 & 300.00 & 300.00 \\
\hline Planting & 400.00 & 400.00 & 400.00 & 400.00 \\
\hline Seeds & 450 & 450 & 450 & 450 \\
\hline Irrigation & 800 & 800 & 800 & 800 \\
\hline \multicolumn{5}{|l|}{ Mineral fertilization } \\
\hline Ammonium nitrate $(33.5 \% \mathrm{~N})$ & 600 & - & - & - \\
\hline Compost- tea & - & 950 & - & - \\
\hline Humic acid & - & - & 340 & - \\
\hline Bio-fertilization & - & - & - & 580 \\
\hline Super phosphate $\left(15.5 \% \mathrm{P}_{2} \mathrm{O}_{5}\right)$ & 550 & 550 & 550 & 550 \\
\hline Potassium sulphate $\left(48 \% \mathrm{~K}_{2} \mathrm{O}\right)$ & 630 & 630 & 630 & 630 \\
\hline Hoeing & 600 & 600 & 600 & 600 \\
\hline Harvesting & 500 & 500 & 500 & 500 \\
\hline Total variable cost & 4830 & 5180 & 4570 & 4810 \\
\hline Yield ton /fed & 50.14 & 55.89 & 60.04 & 64.53 \\
\hline Price Yield/ ton & 350 & 350 & 350 & 350 \\
\hline Seeds ton /fed & 0.199 & 0.238 & 0.256 & 0.273 \\
\hline Price Seeds /ton & 30 & 30 & 30 & 30 \\
\hline Total revenue & 17,555 & 26,702 & 21,022 & 30,776 \\
\hline Net return & 12,725 & 21,572 & 16,452 & 25,966 \\
\hline Return of invested L.E. & 3.63 & 5.15 & 4.60 & 6.40 \\
\hline Net return of invested L.E. & 2.63 & 4.15 & 3.60 & 5.40 \\
\hline
\end{tabular}

It is clear that from date the minimum total costs were those of application of bio-fertilizer being 4570 L.E then maximum total costs of plants received the Compost$\mathrm{T}$ rate which was 5180 L.E. Average over all treatments of total costs were 4847.5 L.E.
Net return

Results in Table (10) reveal that the highest net farm return were recorded in T4 $\left(25,966\right.$ L.E.fed $\left.{ }^{-1}\right)$ followed by the T2 (21,572 L.E.fed $\left.{ }^{-1}\right)$ and T3 (16,452 L.E.fed. $^{-1}$ ) while, gave the lowest value in control $\mathrm{N}$ 
fertilization $\left(12,725\right.$ L.E.fed. $\left.{ }^{-1}\right)$. The highest value of net return per one invested L.E. was recorded of application Humic acid and Compost-T compared with control $\mathrm{N}$ fertilization (6.40 and 5.15 L.E.), followed by bio-fertilizer and control (4.60 and 3.63 L. E.) respectively. The result in table (10) was highest total revenue L. E. fed ${ }^{-1}$ by Humic acid fertilizer (5.40) than other treatment, followed the lowest net return of invested were (2.63 L.E.) recorded by control. Generally, it could be concluded that most yield and yield components, plant height, fresh yield, dry yield, protein contents, digestible crude protein, total carbohydrate, fiber fraction and weight of seeds, weight of 1000 seed were have been increased with applying foliar of humic acid. The effect of combination between compost, bio fertilizer, humic acid and nitrogen fertilizers showed a significant effect on all Qualities and its components under study in soil salinity, it is obvious from the result that forage berseem clover cultivar fertilized with foliar humic acid gave the highest values for most characters under study.

\section{ACKNOWLEDGEMENT}

Thanks for all consideration are based on official and actual market prices resolved by Muhamed Abd ElHalim the Ministry of Agriculture and the Agricultural Credit and Development Bank.

\section{REFERENCES}

A.O.A.C. (1990). Official Methods of Analysis. Association of Official Analysis Chemists. $11^{\text {th }}$ Ed., P. O. Box 540, Washington, D. C. USA.

Abdel Gawad, M.A.S. (2003): Variation on quantity and quality of some berseem cultivars (Trifolium alexandrine L.) J. Agric. Sci. Mans. Univ., 28 (2): 719-728.

Abdel-Aal, S. I.; Abdel-Hamid, M. A.; Ismaiel, S.A.; Abdel-Fattah, A.; and Abdel-Aalab A.S. (2003). Effect of organic farming practice on nutrient availability and wheat yield grown on torripsamments. Egypt. J. Soil Sci. 43 (1): 47-62

Abdurrahman, H.; B. Fatih, M. Fatih and Y. Mustafa, (2004). Reclamation of saline-sodic soils with gypsum and MSW compost. J. Compost Science \& Utilization, 12(2): 175-179.

Abotaleb, H.H.Y.; M.A.S. Abdel Gawad and El-Khatib Elham. A. (2008): Effect of bacterial inoculation on quality and yield performance of three Egyptian clover cultivars.Proceedings (The Second Field Crops Conference), ARC, FCRI, Egypt, 14-16 Oct., pp. 191-202.

Boris, P.;B. Eyheraguibel; M. Morard and J. Silvestre, ( 2010). Direct effects of humic-like substance on growth, water and mineral nutrition of various species. J. Plant Nutr., 34: 46-59.

Brunner, P. H. and Wasmer, H. R. (1978). Methods of analysis of swage sludge solids wastes and compost. WHO international Reference Center for wastes Disposal. CH-8600 Dubendorf, Switzerland.

Chapman, H.D. and P.F. Pratt (1978). Methods of analysis for soils, plants and waters. Univ. California, Div., Agric. Sci. Priced. Pub. 4034.
El-Nahrawy, M.A.Z. (2005).The vital role of Egyptian clover in agriculture. Proceedings of the $11^{\text {th }}$ Conference of Agronomy, November 15-16, 2005, Assiut University, Assiut, Egypt.55-62.

El-Sadfy, O. F., Bioumy, A.M.M. and Badawy, A.A. (2005). Response of maize to bio, organic and nitrogen fertilization in sandy soil. Egypt J. Agric. Sci. 20 (11) 269-284.

El-Sebaey M. M. (2006). Effect of Inorganic, Organic and Bio-Fertilizer on Wheat Plant Grown in New Cultivated Land. Zagazig J.Agric. Res., 33 (5): 863-867

Ferrara, G. and G. Brunetti (2010). Effects of the times of application of soil humic acid on berry quality of table grape (Vitisvinifera L.) cv Italia. Spanish J. Agric. Res., 8(3): 817-822.

Gehan, H. Youssef, (2006). Effect of rice straw compost and mineral nitrogen fertilizer on some sandy soils chemical properties and nitrogen use efficiency for maize and wheat plants. J.Agric. Sci Mansoura Univ., 31 (9): 6079-6100.

Gomez, K.A. and Gomez, A.A. (1984). Statistical Procedures for Agri. Res., 2nd ed., Wiley, New York.

Graves, W.L; W.A. Williams and C.D. Thomson (1996). Berseem clover: A winter annual forage for California agriculture. University of California Division of Agriculture and Natural Resources, Publication No. 21536, pp. 12.

Hammad, S.A.; El-Hamdi, K. H., Ghanem S.A., and Naeem, E.S. ( 2006 ). Impact of rice straw on availability of some nutrient elements in flooded rice soils. J. Agric. Sci. Mansoura Univ. 31 (6) : 4007-4015.

Hannaway, D. B. and Larson, C. (2004). Berseem Clover (Trifolium alexandrinum L.). Oregon State University,.

Heckman J. James (2006) Effect of Olive-Mill Wastewater Application, Organo-Mineral Fertilization, and Transplanting Date on the Control of Phelipanche ramosa in Open-Field Processing Tomato Crops. Available from: [accessed Oct 15 2018].

Heuzé V., Tran G., Boudon A., Bastianelli D., Lebas F., 2016. Berseem (Trifolium alexandrinum). Feedipedia, a programme by INRA, CIRAD, AFZ and FAO. http://www.feedipedia.org/node/248 Last updated on March 29, 2016, 16:15

Hoitink, A.J. Harry and Fahy, C. Peter (1986). Basis For The Control of Soil Borne Plant Pathogens With Composts. Annual Review of Phytopathology Vol. 24; 93-114.

Holah, S. Sh. ( 1990 ). Influence of waterlogging and organic matter addition on the distribution of micronutrents in some soils of Egypt. Egypt J. Soil Sci. (30):677-691.

Hussein, Kh. and Hassan, A.F. (2011). Effect of different levels of humic acids on the nutrient content, plant growth and soil properties under conditions of salinity. Soil and Water Res., 6(1): 21-29.

Jackson, M.L., (1976). Soil Chemical Analysis. Constable and Co. L.T.P., London, England. 
Khaled, A.; Shaban; Mona, G.; Abd El-Kader; Seham, M. and El-Khadrawy (2011). Evaluation of organic farm and compost combined with urea fertilizers on fertility and maize productivity in newly reclaimed .Res. J. of Agri. and Bio. Sci., 7(5): 388-397, ISSN 1816-1561.

Kunelius. T. (1997) "Growing Berseem Clover, Percian Clover and Hairy Vetch" Crops and Livestock Research Centre, Agriculture and Agri-Food Canada. Agri-Info, 97-05, Bulletin. 10 p.

Laidlaw, A.S. and Teuber, N. (2001) Temperate Forage Grass-Legume Mixtures: Advances and Perspectives. Proceedings of the 19th International Grassland Congress, Sao Paulo, 11-21 February 2001, 85-92.

Litterick, A.M.; Harrier, L.A.; Wallace, P.; Watson, C.A.; Wood, M. (2004). The role of un composted materials, composts, manures and compost extracts in reducing pest and disease incidence and severity in sustainable temperate agricultural and horticultural crop production. Crit. Rev. Plant Sci. 2004 ,23, 453-479, ISSN 0735-2689.

Mariangela, D. and Francesco, M. (2015). Effectiveness of organic wastes as fertilizers and amendments in salt -affected soils. J. Agri.. 5 : 221- 230.

Mc Donald, P.R., A. Edward and J.F. Greenhalgh (1978). Animal nutrition Longman Group up. London, UK.

Mekail, M.M. (2006). Evaluation of some natural organic wastes as amendments for virgin coarse texture soil. 4. Date palm tree wastes, composting and compost fertilizing value. Minia J. Agric. Res. And Dev.,26 (1) 1- 26.

Modaihsh, A. S.; Taha, A. A. and Mahjoub, M.O. (2005). Impact of some compost on wheat plant grown in calcareous soils. J. Agric. Sci. Mansoura Univ. 30 (12) 8313-8321

Mohamed M. Hussein, and Ashok K. Alva (2014). Growth, Yield and Water Use Efficiency of Forage Sorghum as Affected by Npk Fertilizer and Deficit Irrigation. American J. of Plant Sci., 5, 2134-2140

Mostafa M. A. ,. Gawish Sh. M and. Basyouny E. A (2001) Effect of enriched organic manures with Fe and $\mathrm{Zn}$ on the availability of $\mathrm{Fe}$ and $\mathrm{Zn}$ in newly reclaimed soils. Minufiya J. Agric. Res.. 26 (6) : $1667-1680$

MSTAT-C (1990). A Microcomputer Program for the Design, Management, and Analysis of Agronomic Research Experiments. Michigan State Univ., USA.

Nasef, M.A., Shaban, Kh.A. and Abdel Hameed, A.F. (2009) Effect of compost and bio-fertilizer application on some chemical soil properties and rice productivity under saline soil condition. J. Agric. Mansoura Univ., 34 (4): 2609- 2623.

Nor El-Din, M.A. (1978) Effect of Berseem-Ryegrass Mixtures on Forage Yield. M.Sc. Thesis, Al-Azhar University, Cairo.

Nordi S., Pizzeghello D, Renero F. and Muscobo A. (1999) Biological activity of humic substances extracted from soil under different vegetation cover commun. Soil Sci. Plant Anal. 30:621-634.
Page A.L. , Miller, R.H. and Keeney D.R. (1982). Methods of Soil Analysis 11- Chemical and Microbiological properties. Soil Sci. Amer. Madison Wisconsin, U.S.A.

Pagliai, M.; N. Vignozzi, and S. Pellegrini.(2004). Soil structure and the effect of management practices. Soil Tillage Res. 79:131-143

Pant A, Radovich TJK, Hue NV, and Arancon ,N.Q.(2011). Effects of vermicompost tea (aqueous extract) on pak choi yield, quality, and on soil biological properties. Compost Sci. Util. 4: 279-292

Rebeka, S.L. (2006). Composting as an alternative method to dispose of slaughterhouse wastes in Puerto rice.MSc. Thesis Animal industry.Univ. Puerto Rico.Mayaguez Campus.

Richards, A.L. and I.R. Weaver, (1944). Moisture retention by some irrigated soils as related to soil moisture tension. J. Agric. Res., 29: 215-235.

Richards, L.A. (1954). Diagnosis and Improvement of Saline and Alkaline Soils.US Salinity Lab. Staff. Agric. Handbook, No. 60.

Samah S.O. and Bashandy (2007). Recycling of Date palm Wastes as a Source of Organic Fertilizer. M. Sc Thesis, Fac. Agric. Minia Univ. Egypt.

Scheuerell S.J. and Mahaffee W.F. (2004). Compost tea: Principles and prospects for plant disease control. Compost Sci. Utiliz. 10: 313-338

Sebastiano Delfine, Roberto Tognetti; Ersilio Desiderio and Arturo Alvino (2005). Effect of foliar application of $\mathrm{N}$ and humic acids on growth and yield of durum wheat. Agron. Sustain. Dev. Volume 25, Number 2,183 - 191.

Shaban, Kh. A. and Omar, M. N. (2006). Improvement of maize yield and some soil properties by using nitrogen mineral and PGPR group fertilization in newly cultivated saline soils. Egypt. J. Sci., 46(3): 329- 342.

Shaban, Kh.A. ; Ahmed, H. M. R. M. and El- Maaz E. I. M. (2013).Effect of mineral, organic and biofertilizations and cultural practices on some soil physical properties and wheat productivity in saline soil. Egypt. J. of Appl. Sci., 28 (11):372-393.

Simsek, M., Can, A., Denek, N., Tonkaz, T., 2011. The effects of different irrigation regimes on yield and silage quality of corn under semi-arid conditions. Afr. J. Biotechnol. 10, 5869-5877.

Singaroval R, Belasubramanian TN, Govindasamy R. (1993). Effect of humic acid on sesam (sesamum indicum) Indian j. Agron, 38:147-149.

Sommers L.E., and Nelson, D.W. (1972). Determination of total phosphorus in soils. A rapid perchloric acid digestion procedure. Soil Sci. Amer. Proc. 36: 902904.

Suttie, J. M., (1999). Berseem clover (Trifolium alexandrinum). A searchable catalogue of grass and forage legumes, FAO.

Tandon, H. L. S. (2000). Fertilizer organic manures wastes and bio-fertilizers components of integrated plant. Fertilizer Development and consultation organization 204- 204, A Bhanot Corner, 1-2 Pamposh Enclave New Delhi. 110048. India. 
Türkmen, Ö.; S.Demir; S. Ensoy,and A.Dursun, (2005). Effects of mycorrhizal fungus and humic acid on the seedling development and nutrient content of pepper grown under saline soil conditions. J. Biol. Sci., 5(5): 568-574.

Vengadaramana, A .and Jashothan, P.T.J . (2012). Effects of organic fertilizers on the water holding capacity of soil in different terrains of Jaffna peninsula in Sri Lanka. J. Nat. Prod. Plant Resour, 2(4): 500-503.

Waldo, D.R. and Jorgensen, N.A. (1981) Forages for High Animal Production: Nutritional Factors and Effects of Conservation. Journal of Dairy Science, 64, 1207-1229. http://dx.doi.org/10.3168/jds.S0022$0302(81) 82697-5$.
Yigit, F. and M. Dikilitas, (2008). Effect of humic acid applications on the root-rot diseases caused by Fusarium spp. on tomato plants. Plant Pathol J. (7):179-

Zheljazkov, V.D. and P.R. Warman, (2004). SourceSeparated Municipal Solid Waste Compost Application to Swiss chard and Basil. J. Environ. Qual., 33: 542-52

\section{تحسين إنتاجية وجودة البرسيم المصري باستخدام التسميد الحيوى و العضوي تحت ظروف الأراضي الجديدة الملحية

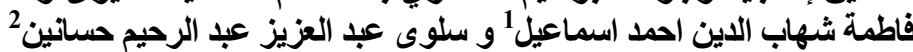

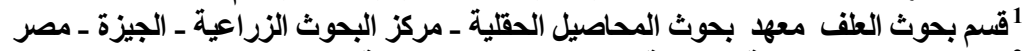

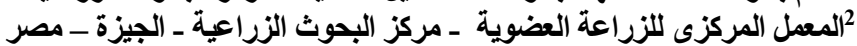

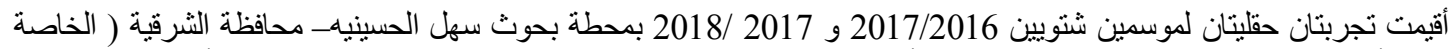

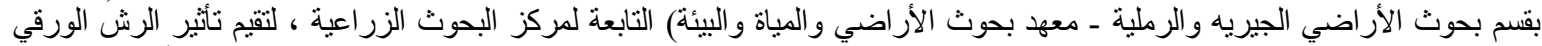

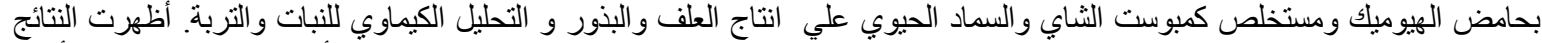

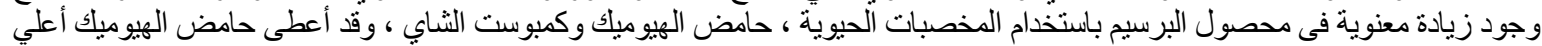

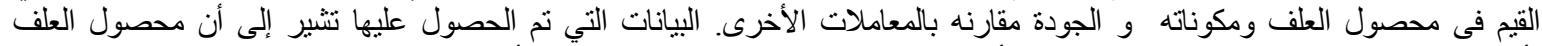

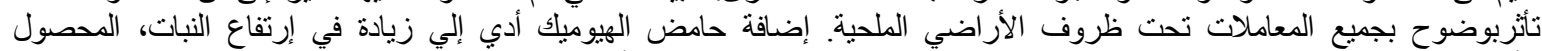

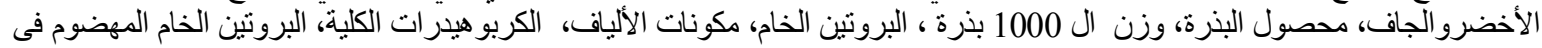

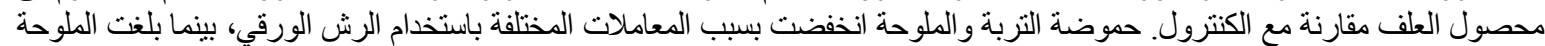

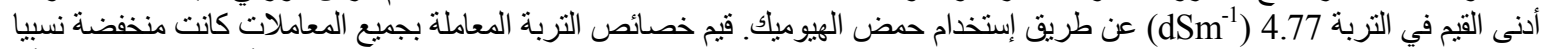

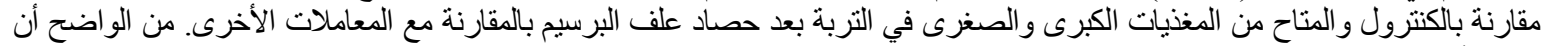

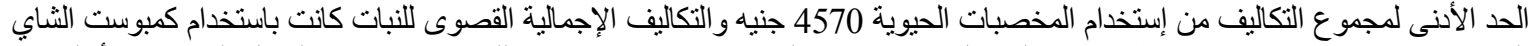

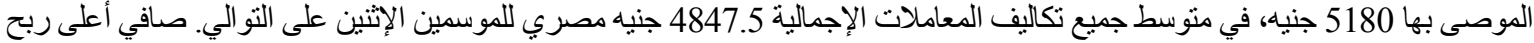

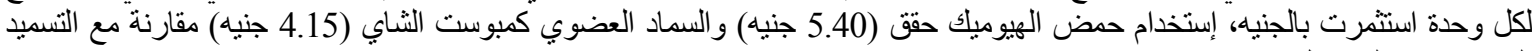
النيتروجيني (الكنترول 2.63). 